\begin{tabular}{c} 
Volume and Issues Obtainable at Center for Sustainability Research and Consultancy \\
Journal of Business and Social Review in Emerging Economies \\
ISSN: 2519-089X \& ISSN (E): 2519-0326 \\
Volume 7: Issue 3 September 2021 \\
CSRᄃ \\
Journal homepage: www.publishing.globalcsrc.org/jbsee \\
\hline
\end{tabular}

\title{
Analysis of Teachers Instructional Planning and Developing Skills of Social Responsibility at FGP Secondary Schools Level in KP Pakistan
}

*Javeria Rauf, Institute of Education \& Research, University of Peshawar, Pakistan Hafiz M. Inamullah, Institute of Education \& Research, University of Peshawar, Pakistan

*Corresponding author's email: javeriarauf@outlook.com

\begin{tabular}{l}
\hline ARTICLEDETAILS \\
\hline History \\
Revised format: Aug 2021 \\
Available Online: Sep 2021
\end{tabular}

Keywords

Teachers, Skills, Social Responsibility, Pakistan

\section{JEL Classification}

$I 2, I 20$

ABSTRACT

Purpose: The study was conducted to analyze the methods adopted by teachers towards instructional planning and to analyze the mechanism used by teachers to develop sense of social responsibility among students.

Methodology: For this purpose data was collected from the respondents regarding Instructional Planning; majority of the respondents opinioned that Lesson plan was written occasionally with specific and clear objectives. Data was collected regarding social responsibility, majority of the respondents were always aware about Self hygiene, cleanliness through lectures and activities. Recommendations are stated that teachers must write lesson plans and it must be ensured by school administration. Community service programs must be integral part of the curriculum. Moreover, different clubs at school and seminars aid in socially grooming of students.

Findings: Conclusion of the lesson, home assignment was included considering organizing the lesson according to learner`s needs, evaluation, time specification, flexibility of the planner considering outcome of pupils, visualizing with classroom reality, group discussion, pupil`s group work, presentations and encouraged students' relevant questions. Moreover, the instructional planning was significant.

Implications: Teachers must guide the pupils in Community Service and create awareness in pupils for its importance not only in their career but also in providing community services, developing sense of responsibility, morality, skills development and citizenship. Parents' cooperation is also prerequisite in motivating the pupils towards Community services

(C2021The authors, under a Creative Commons AttributionNonCommercial 4.0

Recommended citation: Rauf, J. and Inamullah, H. M. (2021). Analysis of Teachers Instructional Planning and Developing Skills of Social Responsibility at FGP Secondary Schools Level in KP Pakistan. Journal of Business and Social Review in Emerging Economies, 7(3), 629648. 


\section{Introduction}

\section{Background of the Study}

The profession of teaching plays a cardinal role in grooming new generation. Teachers not only act as a beacon house of knowledge but also mold the pupils' personality and guide them for their career as well. Professional teachers lay foundation stones not only in education of their pupils, but also in their successful career. Baggini (2005) stated that the term 'Professional or a 'Professor' is rooted in Latin word 'Profess' which means to be proficient in any area of knowledge. It is essential to analyze elements of professionalism in general and then in teaching profession. Hoyle and John (1995) stated that, a profession is an occupation that performs a dynamic social role, it needs substantial skill and systematic knowledge. Skill is developed from educational training gained through socialization. A professional has specialized knowledge inculcated with technical aspects and commitment to meet client's needs. This professional commitment is to be considered by teachers in teaching.

Evans (2011) described professionalism as to refine skills and knowledge, to gain mastery in any field. Developing professionally narrowly refers to the training provided to the teachers to improve their practice, including a wide range of activities that would change professional thinking, knowledge, feeling and working. He believed in improvement of behavior of teachers. The attitude of teachers towards learners and teaching methodologies. Evans (2011) further added that professionalism also includes Mentoring and Coaching, innovation and action research by teachers.

Hoyle (2001) stated professionalism is related to the improvement in quality of work than status. Shanker (1985) recommended establishing Experimental schools within the schools. New teachers may be provided opportunity to work with proficient teachers and incompetent teachers may be removed and outstanding teachers need to be rewarded by providing extra pay. Workshops on teacher's education, Critical thinking, School finances, role of teachers in society, conducive environment, and quality education need to be a regular feature in training the teachers and leading them towards professionalism. Individuals need to be trained at professional Colleges or universities. Elements of Professionalism are briefly demonstrated in Fig. 1.1:

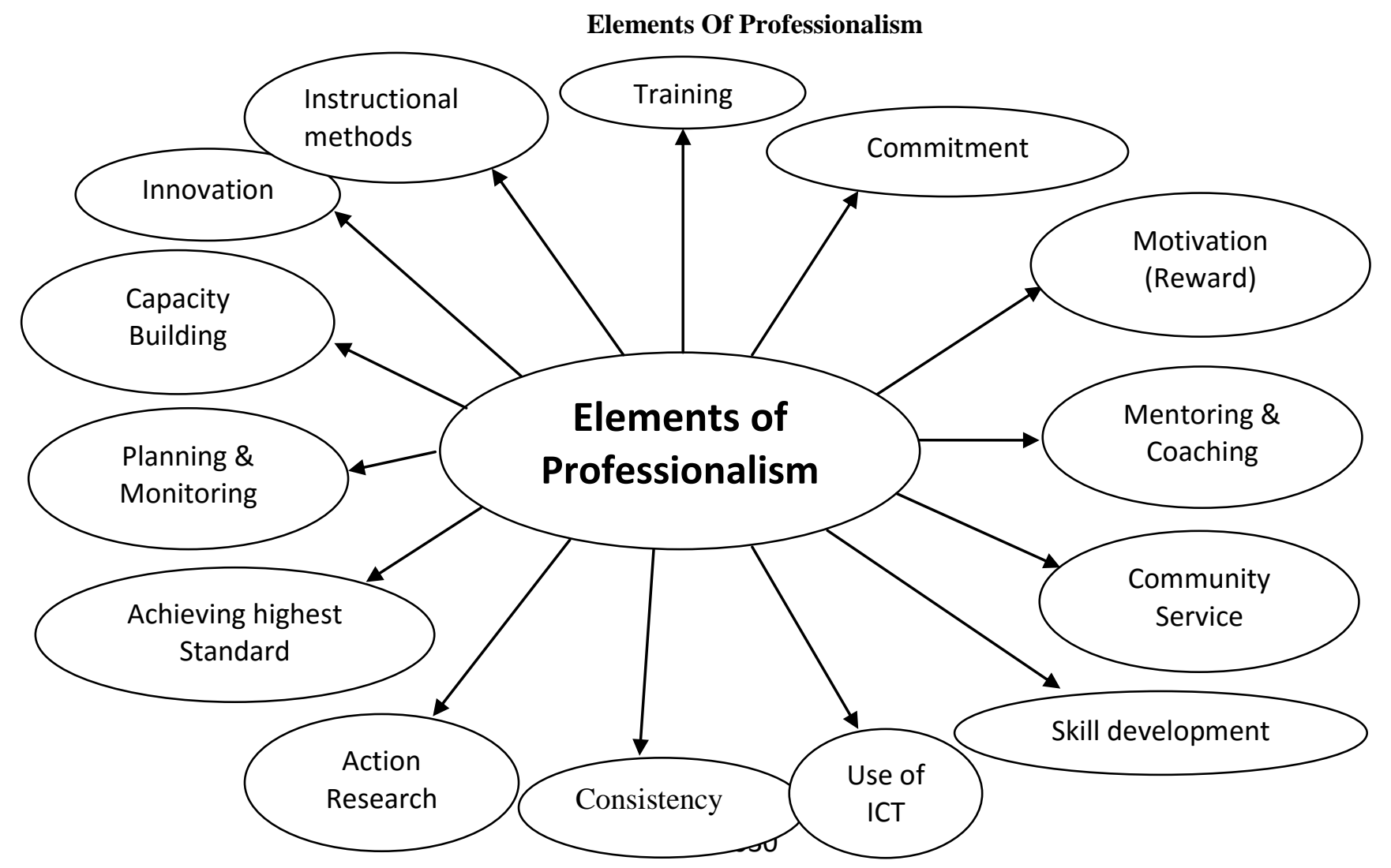


Figure 1.1 Elements of Professionalism

Shanker (1985) further defined a professional as an adept, skillful knowledgeable person as a Surgeon at Surgery, who knows the direction to cut. But need to step ahead by introducing innovative methods and providing self-respect with financial benefits, Motivation and lifetime commitment along with accountability to gain excellence. A professional has a strong sense of responsibility and is accountable to the society as teaching is an honorable profession and requires dedication.

Shanker (1985) further stated professional teachers are not slaves to rules of education department, textbooks rather they are reflective decision makers, selecting objectives and methods according to learners needs. To promote professionalism in teaching through a democratic mind, mastery over subject matter, being vigilant and responsible for gaining professionalism.

National educational policy (2009) defined the professional standards that need to be attained through the command on the subject, promoting ethical values, Islamic norms, evaluation, planning for teaching methodologies, conducive environment, use of ICT, teamwork, grooming professionally and teaching of English language in order to excel internationally. Robinson (1993) explained quality in teaching as a creation of plan, supervision, and harmony. Gandhe (2010) considered the standard in teaching as to gain the highest level, to be consistent, to be serving the purpose, considering the worth of financial benefits in teaching in order to gain professionalism.

Phelps (2006) stated professionalism is measured by the best practices and achieving highest standards. Sachs (2003) expressed it as improving work environment; Hangreaves (2000) considered it as carrying out directions of superiors in teaching and choosing the best method which is most beneficial for pupils. Professionalism is a broad and dynamic term. It includes high level of interest, considering social responsibility more than personal responsibility by teachers. The researcher in current study will focus on the following three aspects of teachers professionalism: to evaluate the commitment of teachers through Principals; to analyze the mechanism which would develop sense of social responsibility in pupils and to analyze the methods adopted by teachers for instructional planning?

Wiggins and McTighe (1998) emphasized that teachers must be clear about the learning goals they have for their students. If teachers have a vivid vision of instructional objectives and strategies the pupils will groom, which reflects professionalism in teaching. Munn, Colskey and Butler (2003) suggested steps for improving teacher's professionalism and building capacity of teachers. Probing is the first step which involves keeping in view the need of capacity building. Vision is required. Then Planning. Teachers need time to discuss, reflect and plan the instructional strategies. Implementation of the planned instructional strategies. Teachers must apply the methodologies learnt during the trainings and workshops. It is necessary for capacity building. Evaluation is the most important step in assessing the commitment of teachers. The administrator evaluates the teachers. Evaluation determines the strengths and weaknesses of teaching and future plans to progress. Action research strategies may be implemented by teachers.

The following fig. 1.2 demonstrates these steps: 


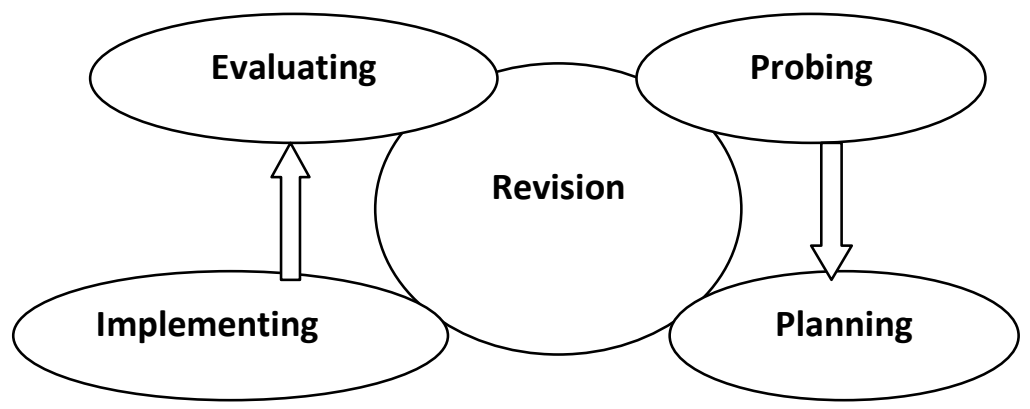

Development of social sense of responsibility by the teachers is also a key feature of professionalism. To prepare students for sharing responsibilities in the community and to work for the common welfare of the society through community service. Fowler (1990) stated that the school curriculum should accommodate democratic values and community service programs. National education Policy (2009) stated that teachers bridge parents, family members and society. They develop role of schools in community through community service programs. It consequently leads towards pupils learning and development in a child friendly school environment. Pupils learn skills through practical experiences and the school gets linked with surrounding community.

Spring, Grimm and Dietz (2008) defined community service as service activities conducted within or outside the school. e.g cleaning up school ground, visiting hospital, distributing food to those in need, helping in medical store. Aim is to offer service to the nation. After community service, classroom discussion is carried out or an article is written with critical analysis. Community service is also known as Service learning. It enables pupils to become active members of society, encourage caring for others, leading towards their social development. John Dewey (1900) and (1919) stated democracy can be inculcated in students, educators and members of society by actively working together to address society`s needs.

Analyzing the teacher's approaches towards instructional planning. Clark and Peterson (1986) stated that teachers thinking process has many facets. It basically has three main stages: Preactive, Interactive and Post active. New ideas are developed in Pre Active stage, the teacher plans before the instruction process begins. He/She makes decisions e.g how to teach under achievers. Interactive stage, the instruction begins joining the new ideas. During Post instruction stage planning continues, the teacher decides about next lesson. Planning of teacher is cyclic, occurring short term or long term. The curriculum is translated to a set of activities. Instructional planning involves instructional objectives and activities. It is the teachers planning of objectives, activities who sets the tone of the classroom, keeping in view the students learning. Egeler (1993); Kennedy (1994) believed that teacher arranges instructional material according to the learner`s mental level. Moreover, time is allocated according to learner's need and school schedule. Hence, overall learner centered approach leads towards professional teaching.

\section{Statement of Problem}

Teaching is a prophetic profession. It is unfortunate to state that teaching at public sector mostly lacks motivation as teachers don't make efforts in planning instructional methods. Moreover, teachers restrict to syllabus only and don't inculcate values of community service. Therefore, the researcher has selected analysis of planning of instructional methods and developing skills of social responsibility at Federal Government Public Secondary Schools in KP, Pakistan.

\section{Objectives of the Study}

- To analyze the methods adopted by teachers towards instructional planning. 
- To analyze the mechanism used by teachers to develop sense of social responsibility among students.

\section{Significance of the Study}

Professionalism plays a cardinal role in teaching. This study is conducted to analyze the planning of instructional methods and developing skills of social responsibility in teachers. The study will enable the researchers and policy makers, to inculcate various elements of Professionalism in curriculum and teachers training programs. Teachers will realize its importance and will work hard with self-motivation, innovation, planning and commitment. It will enable the teachers to improve their instructional techniques and would focus more attention to overall development of pupils personality in curricular and co-curricular activities. The study will enable pupils to improve in education and share responsibilities in society. Community will also be benefited by services provided by pupils through professional teachers.

\section{Delimitation of The Study}

The researcher delimited the study to Federal Government Secondary Schools of KP only due to shortage of time and money.

\section{Methodology}

\section{Population}

The study is Quantitative in nature. Further descriptive research was conducted. Two main elements of professionalism were studied: Instructional planning by teachers and inculcation of social responsibility in pupils by teachers.

One of the important steps of research is to define the population and draw a sample from it to collect data. The population is the collection of individuals possessing the same characteristics (Creswell, 2005) and a group of people from which the researcher intends to collect data (Best and Kahn, 2010).

According to EMIS (2019), there are total 28 Secondary level Federal Government Public Schools in District Peshawar. The total number of male and female Secondary school teachers was 437 in Khyber Pakhtunkhwa province. Thus, the target population comprises of 437 teachers both male and female.

\section{Sample}

The sample of the study is selected by using Random sampling technique. Ghauri and Gronhaug, (2005) described simple random sampling as every case in population has an equal opportunity of being selected. Further, Krejcie and Morgan (1970) table was used to draw the sample. Thus 205 teachers from 27 schools were selected.

\section{Sample of the study}

\begin{tabular}{llll} 
SCHOOLS & & TEACHERS & \\
$\mathrm{N}$ & $\mathrm{n}$ & $\mathrm{N}$ & $\mathrm{n}$ \\
\hline 28 & 27 & 437 & 205 \\
\hline
\end{tabular}

Sampling: From 27 schools total 205 Teachers were randomly selected

\begin{tabular}{lll}
\hline NO OF SCHOOLS & $\begin{array}{l}\text { NO OF TEACHERS } \\
\text { (from each school) }\end{array}$ & SAMPLE \\
\hline 10 & 9 & 90 \\
10 & 8 & 80 \\
7 & 5 & 35 \\
\cline { 2 - 3 } & Total Sample & 205 \\
\hline
\end{tabular}




\section{Tools for Data Collecting}

For the collection of data two research tools were used. Both the tools were developed personally in the light of literature according to the objectives of the study. For measuring Instructional Planning of teachers a self-designed five (05) point likert scale Questionnaire was used for collection of data form the respondents of the study. While for measuring Inculcation of Social Responsibilities by teachers another self-developed five points likert scale was used.

\section{Instructional Planning}

The questionnaire about instructional planning was comprised of 43 questions. Each question is marked in five points likert scale.

\section{Inculcation of Social Responsibilities}

The questionnaire about inculcation of social responsibilities was comprised of 51 questions. Each question is marked in five points likert scale.

\section{Validity and Reliability}

For maintaining the validity of the research, the questionnaire was reviewed by four specialists, comprising of the supervisor; all the specialists were professors of university, having more than ten years of experience of teaching. Some of the items were added and some deducted as per their directions. Then it was overseen by twenty respondents for the sake of pilot study. These were not included in the study. For checking reliability, Cronbach Alpha was applied in order to assess all items, which was .89 or $89 \%$ and .78. Above $60 \%$ of the Cronbach Alpha all values are acknowledged otherwise omitted. (Malhotra, 2004).

\begin{tabular}{|l|l|}
\hline Constructs & $\begin{array}{l}\text { Cronbach Alpha } \\
\text { (Reliability) }\end{array}$ \\
\hline Instructional Planning & .89 \\
\hline Social Responsibility & .78 \\
\hline
\end{tabular}

\section{Procedure For Data Collection}

For the collection of data prior permission was taken from heads of institution for collecting data through questionnaires from their teachers. Most of the data was personally collected. There were some schools of Swat, Nowshera, Mardan, Kohat, who sent their questionnaires through Post, some through email. Data was carefully collected. Then the data was entered in Excel sheet and then to SPSS software. Statistical chi-square method was applied.

\section{Data Analysis}

Data was analyzed through quantitative methods, using Chi Square statistical model. Analysis is presented through Tables. Both the tools are analyzed with the help of Statistical Package for Social Sciences 20.0.

\section{Code of Ethics of Research}

The names of teachers and schools are kept confidential. The researcher coordinated time and availability of teachers, with school authorities. Some teachers emailed their questionnaire as well. On the whole objectivity was observed in the research.

\section{Analysis of Data}

The chapter deals with the analysis of data. The data was gathered through closed ended questionnaire. Then the data gathered was entered in Statistical Package of Social Sciences (SPSS). For obtaining the results frequency, percentages and Chi-square statistical model was applied and results was presented into tabular form.(Tables available with authors) 


\section{Discussion}

Anderson \& Krathwohl (2001) emphasized the importance of lesson planning. Warren (1999) lesson plans are more focused and direct towards specific goal. Majority of the respondents said that Lesson plan was written occasionally. Woodward (2001) stated that lesson plan is in written form and the teacher visualizes the lesson. Clark and Peterson's (1986) believed that the thinking process of novice teacher is different for lesson planning. Moreover, Clark \& Yinger, (1980) stated that the novice teachers spend more time in thinking about the lesson planning rather than writing the instructional plan. They are more focused on internal process of thinking rather than external process of writing. In addition, there was gap between teachings of lesson plan at university level as compared to ground realities at schools. Marzano (2001) believed that written lesson plans provide an indication to administrators as to how teachers use instructional strategies. Warren (1999) stated that lesson plans are more focused and direct towards specific goal. DiPaola and Hoy (2008) expressed that when the lesson plan is in written form then there is more coherence in objectives, activity and evaluation. Ko (2012) stated that lesson plans can be attributed as conventional or alternative. It may be of Tyler`s model or Taaba`s model, or any other model. He added that teachers need to be equally effective in lesson planning as well as instruction, in order to achieve maximum students` success.

Most of the respondents said that Specific Objectives are chosen for the lesson plan and objectives are clear. Zahorik, Halback, Ehrle, and Molnar (2003) believed that unclear objectives lead to ineffective teaching, the students are perplexed, and such teachers only focus on knowledge and skills. Such teachers are only equipped with basic skills but they lack management skills. They lack focus of the lesson and lead to unproductive lessons. Clear learning objectives lead to focused lessons, the teacher and student arrive at their destination. Danielson, (2007) stated that clear learning objectives lead towards a clear road map for the lesson. Polk, (2006) clarity in the lesson and learning objectives is necessary otherwise the teacher is lost in the ocean of information leading to confusion in teacher and students. Koeller \& Thompson (1980) stated that clear learning objectives lead towards clear instruction. If the objectives are not clear then teacher as well as the students will be confused. Clark \& Peterson, (1986) argued that a lesson plan is a mental image of the lesson and is hardly implemented therefore the importance of instructional objectives is also weakened.

Majority believed that motivation of the learner is considered for lesson planning, Most of the respondents were of the view that Previous Knowledge questions are prepared for the lesson, Previous Knowledge is linked with new knowledge in lesson planning. Hebart (2014) stated that pupils are motivated towards the lesson through previous knowledge questions, as it bridges the previous knowledge gained. Ali, M (2017) stated that previous knowledge questions and brief explanation of lesson must be jotted down in the lesson plan. Interesting activities for motivation of students must be added. Majority believed that such teaching method is selected that suits the learners. Wang et al. (1993) described that different methodologies selected by pupils produce different results, exhibited in student's outcome. Stronge (2007) believed that effective teachers implement different methods of teaching, the lessons become more engaging to students. Wang et al. (1993 a) stated that different methods of teaching produce different learning outcomes. Frudden (1984) explained that one kind of teaching method is not suitable for all lessons and subjects. It is not a good practice. Most of the Learners individual differences are considered in lesson planning and consider presentation of objectives before the lesson begins. Gall, Gall, \& Borg, (2007) believed that every individual differed in its thinking therefore his lesson plan would differ. Most of the respondents were of the view that they consider presentation of the objectives before the lesson. Majority respondents stated that they ensure objectives of the lesson are relevant. Bloom (1956)tated that objectives play a vital role in lesson planning. Most of the respondents keep in mind that objectives of the lesson are realistic. Jones, Jones, and Vermette 
(2011) described that a common draw back in newly inducted teachers is that learning objective is not clear as a result they waste most of their time in lecturing. Majority always keep in mind the theme of the lesson is to be presented in the beginning of the lesson. Duchastel \& Merril (1973) cited in Salman et al, (2012) stated that objectives don't make difference if students don't pay attention to the teacher during the lesson. However, if the objectives are presented in the beginning of the lesson it would be more effective. Most of them focus on learner's needs while lesson planning. Majority Plan activities for the lesson, in lesson planning. Marshall (2012) stated meaningful planning is a complicated process. Planning seems to be simple and easy but it is difficult and complex. It is not necessary that it will lead towards meaningful activities. Sesiorina (2014) performed the analysis of teachers' lesson plan. There are five aspects of lesson planning: goals, objectives, activities, media and the assessment. She concluded that improvement is required in formulating behavioral objectives, encouraging student's responsibility and producing learning outcomes. Moreover, she stated that teachers don't focus on creating more activities in two domains i.e. Psychomotor and affective domain. All the three domains are equally necessary to develop in pupils their Knowledge, skills and attitude. All the three domains are not implemented equally in the presentation of the lesson.

Moreover, mostly they include problem-solving exercises in lesson planning. Majority stated that Mind map/ concept map/ flow chart/Diagram are included in lesson planning. Mostly they said that A.V aids are arranged for the lesson are used occasionally. Hunter (1982) believed that diagrams, pictures, models, videos, and other attention-grabbing aids must be integral part of a lesson planner. Marzano, Marzano, Pickering, (2003) stated that in lesson planning activities are to be arranged in logical and systematic order. Majority of respondents considered that critical thinking is evoked through questions. Hebart (2014) stated that questions stimulate critical thinking. Marzano et al. (2001) stated that questions lead towards maximum students learning outcome.

They always considered relevancy with subject matter. Hebart (2014) stated that content of the lesson chosen for teaching must be relevant. They always considered relevancy with paper pattern is checked. Hebart (2014) believed that content selected for instruction must match the subscribed curriculum and its suggested examination paper pattern. Marshall (2012) stated that content and activities must match the mental level of pupils. The pupils will be bored or confused if it is not according to their mental caliber.

They consider variety in teaching methods, very frequently. Panasuk \& Todd, (2005) believed that variety in teaching is necessary along with coherence in the lesson. Zahorik et. al, (2003) effective teachers focus on content to be taught and on method of teaching. They always consider maximum participation of pupils in the lesson. Majority consider variety in lesson planning. Panasuk \& Todd, (2005) believed that variety in teaching is necessary along with coherence in the lesson. Interstate new teacher assessment and support consortium (1992) defined lesson plan as to plan teaching by considering factual information of the subject, pupils, public and goals of curriculum. They always considered to develop skills of pupils like speaking, reading, writing. Also they always enable students to apply the concepts in their practical life and they very frequently consider innovation in instructional methods. John, (2006) stated that in instructional planning when further info is added about size of the class, abilities of pupils, period and material to be used, it becomes more refined. Most of the respondents were Always, enable the students to summarize the lesson. Furthermore, they always consider evaluation of students` Comprehension. Parr \& Edwards, (2004) stated that pupils evaluation through questions must be considered. Many consider that the pupils can analyze the lesson, they can distinguish, they always consider, conclusion of the lesson is included in lesson planning and some assignment is included in lesson planning. Burden and Byrd (2003) defined lesson planning as to ensure pupil`s learning, by innovating, arranging and organizing learning material. 
Strong (2007) stated that pupils can comprehend, synthesize, analyze, conclude, work in groups, discuss. Teachers add home assignment to their planner so that the child can work independently. Pressley et. al, (1998); Wharton-McDonald et. al,(1998) stated that students produced high level literary activities in reading and writing as a result of teachers efforts for designing clear objectives and quality assignments. They always consider to organize the lesson (logical order) according to learner`s needs. Good and Brophy (2004) believed that a logical sequence must be given to the lesson, otherwise students develop misunderstanding in concepts. Robert F. Mager published in (1962) that lesson planning activities are to be arranged in logical and systematic order. Behavioral objectives play a vital role in lesson planning. National education policy published in its revised edition in 2013 that the curriculum emphasizing on a student-centered learning. Teacher is as a guide, as a motivator. Activities are learner centered instead of depending on teachers lecture only. Many consider group discussion is included in the planner and and encouraging group work by pupils. Danielson (2007) supported four main domains of teaching - preparing and planning, conducive classroom environment, and instruction including question answer, discussion, assessment techniques, and flexibility in instruction. Professional responsibilities like maintaining correct record, communicating with families, community may also be considered. Moreover, he explained that instructional objectives must be clear and must be stated in terms of students learning outcome rather than student's activity. They always consider Lesson plan is evaluated. Lesson planner is flexible considering outcome of pupils. Parr \& Edwards, (2004) stated that evaluation is included in the lesson. Lesson plan is time specified. Majority considered lesson plan is flexible considering outcome of pupils and they always considered in the planner that Classroom environment is visualized. Stronge (2007) described seven elements of effective teacher lesson planning: clear learning objectives, creating quality assignments, logically organized lesson, instructional methods, timing, individual differences in learning, lesson plan according to mental age and content must match their age. All these qualities create an effective lesson plan. Harmer (2007) stated that a lesson plan guides a teacher how to adapt to classroom environment. Lesson plan shows relationship of teachers with students. Only a committed teacher plans lesson before hand and gains positive response from pupils. Calderhead (1996) stated that a lesson is planned at different levels and planning is creative, informal, understanding based, flexible, practical and deep thinking based. Planning can be long, short, week wise, day to day and lesson wise as well. Planning is formal as well as informal meeting the requirements of administration.

Many considered that lesson plan is adapted according to classroom reality. McDonald et al. (1998) stated that in low quality classroom students wait for instructional directions whereas in high quality classroom, students are engaged and there is maximum participation of pupils. Lee, Y. A., \& Takahashi, A. (2011) argued that lesson plans no matter how well devised, still teachers and students face problems. Moreover, teachers don't mention in lesson plan how much time they spent on lesson planning. However, Lewis (2009) stated that some teachers spent six hours on lesson planning, by following a template for the lesson plan. All elements of a lesson plan are interrelated. Any one part is missing then the whole lesson is affected. They keep in mind to encourage students' relevant questions during the lesson. Gagne and Briggs (1979) stated that attention is gained by asking questions. Many considered brief presentation by pupils is part of lesson planner. Bloom (1956) stated that objectives play a vital role in lesson planning. Moreover, the instructional planning is significant. Berman, S (1998) argued that a professional teacher should not be assessed only on his academic ability, various aspects of personality traits must also be considered.

The data was collected regarding social responsibility majority of the respondents were always awareness is created in students about Self Hygiene, always awareness is created in pupils about cleanliness through motivational lectures and activities. They said that always pupils are encouraged to keep classrooms and school compounds clean and students help in painting school 
/classroom walls. Wang, et al (1993) stated that personal hygiene is important for healthy life. Hygiene broadly refers to cleanliness of hands, nails, feet, oral, hair. Inadequate cleanliness increases the risk of diseases. Therefore, school teachers and administration should create awareness. As diseases spread from personal contacts, air, water, food. On account of conducive intellectual environment, awareness and regular counselling of students by teachers in hygienic conditions can be controlled. Moreover, personal hygiene courses can be included in the curriculum. Cocurricular activities based on hygiene can be arranged. They consider ocassionally that students plant greenery in the school. Moreover, they said that pupils are encouraged to water plants occasionally. Carly R. Ackley (2009) stated that American Association of School Administrators, started green school movement in order to make school atmosphere, the environment of community and the earth to be healthy. By providing healthy food to the pupils, growing green, painting the school building green, in order to teach the importance of green in the environment. They said that always, pupils help in conducting co-curricular activities. Students help the students weak in studies in free time always and Students help sick students at school. Moreover, they always help other students in Sports. Kayla Rutledge (2020) stated that youth can offer their services beginning from their school circle. Then join club, which will open doors for them for learning skills as well as sending them to locations where their services are required.

It is also very frequently Exhibition of Science and Art projects of students are held at school. Occasionally, Students are encouraged towards Recycling of materials. Occasionally they said that the school facilitates in arrangement of stalls by students to raise income for school welfare. Kayla Rutledge (2020) believed that youth can collect used clothes, furniture, household goods and sale them and donate the money where required. Some items can be given to the under priviliged. They occasionally said that ICT skills are developed in pupils always. Kayla Rutledge (2020) stated that youth can offer their services by technical teaching of technology, by teaching, guiding their fellows, senior citizens, neighbours. They occasionally said that Educational field trips are arranged for students. Kelly (2007) stated that youth learns for trips, as they learn to interact, develop skills of communication. They said that never, students are encouraged to help parents at home.

Always, visit to the hospital/Orphanage is arranged for students. Never, Pupils are encouraged to help in medical stores on weekends. They said that never students are inspired to volunteer to help the needy w.r.t food items, clothing literacy. Swaner (2005) cited the theory supported by Colby, Ehrlich, Beaumont, and Stephens (2003) that pupils must be educated to carry out civic and ethical responsibilities. Colby et al. (2003) emphasized that cognitive and ethical development of pupils is an interrelated process Stephens, Colby, et al (2000) expressed that administration of educational institution must provide funding and staff support to encourage civic and social dedication. Administration should monitor, evaluate and bring changes where required to nurture increased civic commitment.

Career counseling programs/ workshops are arranged at school for students. Professionals are invited to brief about profession/Career choosing, at school always. Occasionally they said that Guidance is provided to the students for vocational training in Vacations. Kelly (2007) stated youth learns vocational skills like communication skills and problem solving capabilities through community service. One gets to improve any communication skills if he/ she is weak at it. Teamwork, budgeting and critical thinking capabilities are also formed. Friga (2003) argued that educational institutions pay less heed to the development of (soft) skills. For fruitful results it is necessary to equip the pupils with skills.

They also said guest speakers were invited for motivational lectures on mental health and Drug abuse. They said that never, inspirational lectures are arranged about inculcation of Ethical 
values and grooming of students. Occasionally said that Students Proctors Board is there at school for discipline maintenance. Puerto Ricans by Estudios Tecnicos (2007) believed that education system doesn't succeed to provide sense of social responsibility Diaz-Gonzalez (2002) stated that there is unfairness, dishonesty, lack of patience and immorality prevailing in the society. Our students have lost the values. Our formal education system must play its role to revive the ethical values using the opportunity of cocurricular experiences. These educational institutions will shape the character of a socially responsible individual. According to suggestions of Wellman (1999), Thomas (1998), Stephens et al (2000), Checkoway (2001), Ramaley (2005) that schools should reframe their curriculum with activities that endorse civic and social responsibility.

Also said that always there is literary society of pupils at school and very frequently they said that there is Science Club at school. They said that never there is Arts society at school. They said that never, there is Arts society at school and never Home Economics society is there for cooking competitions. Never, they said that there is Sports club for students. Never, they said that first aid programs are arranged at school. Always pupils are encouraged to join Gyms, Recreational centers for creating awareness about healthy life style and healthy food. Kayla Rutledge (2020) described that youth forms groups where older kids help the younger ones in reading at the library. They can gather books and donate to the school library. Moreover, helping the illiterate to read and write, in the neighborhood. In addition, join clubs to open the gates for getting awareness and training about other vocations. Never had they said there is Sports club for students. Always, parents were counseled. Always students are taught skills of growing kitchen garden and its marketing, on small scale. Never, students are encouraged to conduct class as a teacher, when any teacher is on leave or otherwise. They said that occasionally, leadership skills are developed in pupils. Estudios Tecnicos, (2002) stated that there is a dire need to teach values of civic education associated social responsibility. Estudios Tecnicos (2007) argued that there is detachment in education system and community, leadership and citizenship. There is lack of civic engagement and awareness of public problems. Although the social media has been creating awareness of social responsibility through stories and programs. Aponte-Hernandez (2002) stated that education should not only prepare individuals for economic wellbeing, rather it should also develop aptitude for social responsibility. Always they said pupils are encouraged to help voluntarily in their neighbourhood with H.W. Puerto Rico Council on Higher Education (2007) mentioned in its report that education system fails to strengthen moral values and sense of social responsibility. Education institutions should produce individuals who are capable to contribute to the solution of social problems.

They said very frequently teamwork in pupils is encouraged in curricular and cocurricular activities. Paul (2005) believed that sharing ones own time, knowledge, skills, resources, experiences, to improve others quality of life as a social responsibility without expecting any benefits. Volunteer service needs to be offered.

They always said that students are inspired to help at home in kitchen through easy recipes. Jacoby (2009) stated that pupils can be engaged in civic services by actively partaking in volunteer service, like working in a soup kitchen and solving public problems. Kayla Rutledge (2020) stated that youth can extend their help in planting fresh fruits and vegetables and then donating them to under priviliged, aiding in yard work in their area. Morever, help can be extended in soup kitchen. Always they said that Pupils are motivated to work independently on home. Students are guided in planning their own Timetable for academics and Social welfare, very frequently. Very frequently, they said Programs are arranged at school for Security and Safety awareness. Occasionally, they said students are encouraged to volunteer for rescue programs. Bowen, (2000) stated that the higher education must produce socially responsible individuals. Pupils who will serve others through their aptitude or as citizens. The world today is 
passing through calamity due to lack of social responsibility. Moral, ethical, social values have departed. Fraud, dishonesty, hatred, injustice and other social ills have increased. Santos y Vargas (1992) argued that institutions of higher education claim to produce socially responsible citizens. But unfortunately education system lacks an integrated, thoughtfully defined purpose of education. The education system has developed numerically, but not qualitatively or philosophically. Puerto Rico Council on Higher Education (2007) the current society lacks social, moral, ethical values. There is rise in corruption, dishonesty, injustice, self-centeredness. Castro, (1976); Lopez-Yustos, (1992) contended that many educational institutions claim that they give importance to learning of social responsibility but practically it is not implemented.

They occasionally said that feedback is taken from students about workshop/programs at school. Occasionally they said that feedback is taken from students about workshop/programs at school. Occasionally they said that feedback is taken from school staff about workshop/programs at school and Very frequently Suggestions are invited from teachers, parents and students about improvement in Community service programs at school. Bruner, J. (1996) argued that ethical and social education is sole responsibility of parents not the school. There is no extra time in the school for the teacher to teach character building to the pupils. Moreover, it is also significant.

\section{Conclusion}

Chief aims of the study were to analyze the methods adopted by teachers towards instructional planning and to analyze the mechanism used by teachers to develop sense of social responsibility among students. For this purpose data was collected from the respondents regarding Instructional Planning; majority of the respondents opinioned that Lesson plan was written occasionally with specific and clear objectives. Considering motivation of the learner as a key factor, previous knowledge questions were prepared for the lesson and linked with new knowledge in lesson planning. Appropriate teaching method was selected that suited the learners, keeping in view individual differences and presentation of objectives prior to teaching. It was kept in mind objectives were relevant, realistic and always theme of the lesson to be presented in the beginning of the lesson focused on learner`s needs activities for the lesson, problem solving exercises, in lesson planning. Moreover, A.V aids were used occasionally. Majority of the respondents were of the opinion that they planned to evoke critical thinking of students through questioning, keeping in view relevancy of the subject matter, paper pattern, scheme of studies and students maximum participation.

Skills development of pupils like speaking, reading and writing, were considered along with practical application. However, variety in teaching methods, in lesson planning and innovation in instructional methods were very frequently considered. Students were enabled to summarize, comprehend, analyze and conclude, the lesson. However, occasionally pupils could synthesize the knowledge. Furthermore, Conclusion of the lesson, home assignment was included considering organizing the lesson according to learner`s needs, evaluation, time specification, flexibility of the planner considering outcome of pupils, visualizing with classroom reality, group discussion, pupil's group work, presentations and encouraged students' relevant questions. Moreover, the instructional planning was significant.

The data was collected regarding social responsibility, majority of the respondents were always aware about Self hygiene, cleanliness through lectures and activities. Pupils were encouraged to keep school, classrooms, clean by helping in painting walls, co-curricular activities, students weak in studies and Sports. However, occasionally, pupils were encouraged to water plants, plant greenery, paint flower pots, exhibition of Science and Art projects, encouraged recycling, facilitation to raise school income by stalls, ICT skill development, field trips. While, very frequently students helped the sick fellows, library group study, developed communication skills. However, students were never encouraged to volunteer, help parents at home and at medical 
store. They visited hospital/ orphanage and literary society of pupils was functional. Occasionally, Career counseling programs were arranged, professionals were invited for briefing about vocation selection, guidance about vocational training, guest speakers were invited for lectures on mental health and drug abuse, Students Proctors Board maintained discipline, parents were counseled. However, they never inculcated ethical values, groomed students, encouraged Arts society, Home Economics society, Sports club, first aid program, arrangement for school donation, encouraged pupils to conduct class as a teacher.

Pupils were encouraged to join gyms, recreational centres, taught skills of kitchen gardening, helped in kitchen, motivated to work independently on home assignments, planned their own timetable. However, very frequently there was Science Club at school, teamwork encouraged in curricular and curricular activities, helped neighbors in H.W. occasionally, leadership skills were developed, volunteer for rescue programs, feedback was taken from students, parents, staff about programs at school. Very frequently, security and safety programs arranged, suggestions were invited from teachers, parents and students about improvement in Community service programs. Moreover, it was also significant.

\section{Recommendations}

1. Principals, administrators must encourage the teachers towards lesson planning. They must ensure that Lesson planning is in written form. As it helps in keeping the teacher on the track during the class and it would help other teachers in future as well.

2. Teachers should not consider lesson planning as a burden or extra activity.

3. Community Service learning must be an integral part of the curriculum.

4. Different clubs at school and seminars help in socially grooming the pupils. Therefore, they may not be considered as extra-curricular or time wasters.

5. Teachers must guide the pupils in Community Service and create awareness in pupils for its importance not only in their career but also in providing community services, developing sense of responsibility, morality, skills development and citizenship.

6. Parents' cooperation is also prerequisite in motivating the pupils towards Community services.

7. Community service helps to bring those students back to school who are tired of routine classes and avoid coming to school. Therefore, marks must be allocated for community service programs.

\section{References}

Ali, M. (2017). The motivated teacher. Karachi: Paramount Books.

Anderson, L. W., \& Bloom, B. S. (2001). A taxonomy for learning, teaching, and assessing: A revision of Bloom's taxonomy of educational objectives. London: Longman.

Aponte-Hernández, E. (2002). Hacia la universidad de autogestión del conocimiento. Revista de Educación de Puerto Rico (REduca), (18), 65-97.

Arizona State University. (2007). A New American University. Retrieved from http://www.asu.edu/president/newamericanuniversity/about/.

Astin, A. (2000). The Civic Challenge of Educating the Underprepared. Civic Responsibility and Higher Education, 124-146.

Atcha, S., Bunch, R., Layke, J., Gentile, M., McGaw, N., \& Samuelson, J. (2001). Beyond Grey Pinstripes. Washington DC: World Resource Institute.

Baenen, N., Yaman, K., \& Lindblad, M. (2003). Accelerated Learning Program (ALP): Grade 3 8 Evaluation, 2001-02. North Carolina: Department of Evaluation \& Research. Wake County Public School System.

Baggini, J. (2005). What professionalism means for teachers today. Education Review, 18(2).

Barba, B. (2005). Educación y valores: una búsqueda para reconstruir la convivencia. Revista 
mexicana de investigación educativa, 10(24), 9-14.

Barba, B. (2005). Educación y valores: una búsqueda para reconstruir la convivencia. Revista mexicana de investigación educativa, 10(24), 9-14.

Bassett, L., Jager D., R., Pocock, L., Munsami, B., \& Ramdutt, N. (2006). Study and master technology: Grade 9 teacher's guide. New York: Cambridge University Press.

Battistoni, R. M. (2000). Service learning and civic education: Education for civic engagement in democracy. Service Learning and Other Promising Practices, 29-44.

Benitez, J. (1943). La reforma universitaria. Boletin de la Universidad de Puerto Rico.

Benjamin, R. W., \& Carroll, S. J. (1998). Breaking the social contract: The fiscal crisis in California higher education. Council for Aid to Education, an independent subsidiary of RAND.

Berkowitz, M. W., \& Fekula, M. J. (1999). Educating for character. About Campus, 4(5), 17-22.

Berman, S. (1990). Educating for social responsibility: Schools must help students fight their

Berman, S. H. (1998). The Bridge to civility: Empathy, ethics, and service. School Administrator, 55(5), 27-32.

Berman, S., \& LaFarge, P. (Eds.). (1993). Promising practices in teaching social responsibility: In teaching social responsibility. SUNY Press.

Billig, S. H. (2002). Support for K-12 service-learning practice: A brief review of the research. Educational Horizons, 80 (4), 184-189.

Bloom, B. S. (1956). Taxonomy of educational objectives: Cognitive domain. London: Longman and Green Co Ltd.

Bogdan, R. C., \& Biklen, S. K. (1998). Qualitative research for Education. An Introduction to Theory and methods (3rd ed.). Boston: Allyn \& Bacon.

Bornstein, D. (2007). How to change the world: Social entrepreneurs and the power of new ideas. Oxford: Oxford University Press.

Bowen, W. G., Bok, D., \& Nygren, T. I. (2019). The shape of the river: Long-Term

Boyer, E. L., \& Hechinger, F. M. (1981). Higher Learning in the Nation's Service. A Carnegie Foundation Essay. Carnegie Foundation for the Advancement of Teaching, 1785 Massachusetts Avenue, NW, Washington, DC 20036.

Boyte, H. C., \& Hollander, E. (1999). Wingspread declaration on renewing the civic mission of the American research university.

Bracey, G. W. (2006). Dropping in on dropouts. Phi Delta Kappan, 87(10), 798.

Brookhart, S. M., \& Freeman, D. J. (1992). Characteristics of entering teacher candidates. Review of educational research, 62(1), 37-60.

Bruner, J. (1996). The culture of education. Harvard University Press.

Brunsma, D. L. THE ASHGATE RESEARCH COMPANION TO BLACK SOCIOLOGY.

Burden, P. R., \& Byrd, D. M. (2003). Methods for effective teaching: Meeting the needs of all students (p. 408). Allyn \& Bacon.

Bybee, R. W., Taylor, J. A., Gardner, A., Van Scotter, P., Powell, J. C., Westbrook, A., \& Landes, N. (2006). The BSCS 5E instructional model: Origins and effectiveness. Colorado Springs, Co: BSCS, 5, 88-98.

Campus Compact (2006). Who we are? Retrieved from http://www.compact.org.

Castro, A. (1976). Higher education in Puerto Rico, (1898-1956). A Dissertation Submitted to the Graduate Committee of Lehigh University in candidacy for the Degree of Doctor of Education in School of Education.

Celce-Murcia, M., \& McIntosh, L. (1991). Teaching English as a second or foreign language.

Chakraborty, S. K., Kurien, V., Singh, J., Athreya, M., Maira, A., Aga, A., .. \& Khandwalla, P. N. (2004). Management paradigms beyond profit maximization. Vikalpa, 29(3), 97-118.

Chambers, T. C. (2005). The special role of higher education in society: As a public good for the public good. Higher education for the public good: Emerging voices from a national movement, 3-22.

Checkoway, B. (2001). Renewing the civic mission of the American research university. The 
Journal of Higher Education, 72(2), 125-147.

Chickering, A. W. (1969). Education and identity. San Francisco: Jossey-Bass.

Chickering, A. W., \& Stamm, L. (2002). Making our purposes clear: Getting beyond conflicting priorities and competing interests. About Campus, 7(2), 30-32.

Clark, C. (1986). Teacher's thought process. Handbook of Research on Teaching New York, 255296.

Clark, C. M., \& Yinger, R. J. (1979). Three Studies of Teacher Planning. Research Series No. 55.

Clark, C. M., \& Yinger, R. J. (1980). The Hidden World of Teaching: Implications of Research on Teacher Planning. Research Series No. 77.

Clark, C., \& Lampert, M. (1986). The study of teacher thinking: Implications for teacher education. Journal of teacher education, 37(5), 27-31.

Colby, A., Beaumont, E., Ehrlich, T., \& Corngold, J. (2003). Educating for democracy: Preparing undergraduates for responsible political engagement (Vol. 6). John Wiley \& Sons.

Cotto-Morales, L. (2002). Proyectos alternativos universitarios de fin de siglo y la relación universidad-sociedad. Revista de Educación de Puerto Rico (REduca), (18), 152-174.

Covey, S. R. (1989). The 7 Habits of Highly Effective People: An Extraordinary Step-by-step Guide to Achieving the Human Characteristics that Really Create Success. Simon and Schuster.

Crawford, R. (2017). Rethinking teaching and learning pedagogy for education in the twentyfirst century: blended learning in music education. Music Education Research, 19(2), 195-213.

Creswell, J. W. (2002). Educational research: Planning, conducting, and evaluating quantitative (pp. 146-166). Upper Saddle River, NJ: Prentice Hall.

Cutshall, R., Gavirneni, S., \& Schultz, K. (2007). Indiana University's Kelley School of Business uses integer programming to form equitable, cohesive student teams. Interfaces, 37(3), 265-276.

Danielson, C. (2007). Enhancing professional practice: A framework for teaching. ASCD.

Dewey, J. (1957). Reconstruction in philosophy (No. 48). Beacon Press.

Dewey, J. (1966). Democracy and education (1916). Jo Ann Boydston (ed.). The Middle Works of John Dewey, 9, 1899-1924.

Dewey, J. (Ed.). (1900). The elementary school record (Vol. 1). University of Chicago Press.

Diaz-Gonzalez, A. (2002). Segundo mensaje del Rector del Recinto Universitario de Rio Piedras, Abrahan Diaz-Gonzalez, a los miembros del claustro el dia 9 de abril de 1969. Cited In A. Diaz-Gonzalez (Ed.), Universidady sociedad (pp. 69-113). San Juan, PR: Editorial de la UPR.

DiPaola, M., \& Hoy, W. K. (2013). Principals improving instruction: Supervision, evaluation, and professional development. IAP.

Dunn, R., Beaudry, J. S., \& Klavas, A. (2002). Survey of research on learning styles. California journal of science education, 2(2), 75-98.

Education, 104(A), 351-353. Retrieved from the Education Research Complete database.

Egeler, D. J. (1993). Factors That Influence the Instructional Planning of Teachers. Educational Planning, 9(3), 19-37.

Eggen, P. D., \& Kauchak, D. (1999). Educational psychology (Vol. 403). Prentice hall.

Ehrlich, T. (Ed.). (2000). Civic responsibility and higher education. Greenwood Publishing Group.

Evans, L. (2011). The 'shape'of teacher professionalism in England: Professional standards, performance management, professional development and the changes proposed in the 2010 White Paper. British educational research journal, 37(5), 851-870.

feelings of powerlessness by developing their sense of community and their confidence that they can make a difference in the world. Service Learning General, 75-80. 
Fowler, D. (1990). Democracy's next generation.

Friga, P. N., Bettis, R. A., \& Sullivan, R. S. (2003). Changes in graduate management education and new business school strategies for the 21 st century. Academy of Management Learning \& Education, 2(3), 233-249.

Frudden, S. J. (1984). Lesson plans can make a difference in evaluating teachers. Education, 104(4).

Fujimoto, K. (2014). The Development of CA McMurry's Type Study: Emergence of a Unit Development Theory Embedding Teacher Training. Educational Studies in Japan, 8, 117-128.

Furco, A. (2001). Advancing service-learning at research universities. New Directions for Higher Education, 2001(114), 67-78.

Furco, A. (2007). Institutionalising service-leaming in higher education. Higher education and civic engagement: International perspectives, 65.

Gagné, R. M., \& Gagné, R. M. (1985). Conditions of learning and theory of instruction. Holt, Rinehart and Winston.

Galton, M., Hargreaves, L., \& Comber, C. (1998). Classroom practice and the National Curriculum in small rural primary schools. British Educational Research Journal, 24(1), 43-61.

Gandhe, S. K. (2010). Quality assurance in open and distance learning in India. Open Praxis, 4(1), 26-32.

Ghauri, P., Grønhaug, K., \& Strange, R. (2005). Research methods in business studies. Cambridge University Press.

Ginnis. P (2018) The teacher's toolkit. Karachi: Paramount

Good, T. L., \& Brophy, J. E. (1991). Looking in Classrooms New York. Harp Collins.

Greeno, J. G., Collins, A. M., Resnick, L. B., Berliner, D., \& Calfee, R. (1996). Handbook of educational psychology.

Hargreaves, A. (2000). Four ages of professionalism and professional learning. Teachers and teaching, 6(2), 151-182.

Harmer, J. (2007). The practice of English language teaching. : Pearson Longman.

Hoy, A. W., \& Weinstein, C. S. (2006). Student and Teacher Perspectives on Classroom Management.

Hoyle, E. (2001). Teaching: Prestige, status and esteem. Educational management \& administration, 29(2), 139-152.

Hoyle, E., \& John, P. D. (1995). Professional knowledge and professional practice. Burns \& Oates.

Hunter, M. C. (1982). Mastery teaching. Thousand Oaks, CA: Corwin Press.

Interstate New Teacher Assessment and Support Consortium (2005). Interstate new teacher assessment and support consortium standards. Washington, DC. Council of Chief State Schools Officers. Retrieved February, 12(2007), 2-3.

Jacoby, B. (2009). Civic engagement in higher education: Concepts and practices. John Wiley \& Sons.

Jalongo, M. R., Rieg, S. A., \& Helterbran, V. R. (2007). Planning for learning: Collaborative approaches to lesson design and review. Teachers College Press, Columbia University.

Jensen, M., Porter, M., \& Ghoshal, S. (2005). Bad for business? Economist,374(8414), pp. 5758.

John, P. D. (2006). Lesson planning and the student teacher: re-thinking the dominant model. Journal of Curriculum Studies, 38(4), 483-498.

Jun, M. K. (2004). The influence of quality technology support on teachers' effective technology integration in relation to the maturity of a school work environment as a professional learning community. The University of Iowa.

Kagan, D. M., \& Tippins, D. J. (1992). The evolution of functional lesson plans among twelve elementary and secondary student teachers. The elementary school journal, 92(4), 477- 
489.

Katz, S. N. (2004). Scholars and teachers: hidden partners for hidden collections. RBM: A Journal of Rare Books, Manuscripts, and Cultural Heritage, 5(2), 115-122.

Kaye, C. (2014). Transforming community service into service learning.

Kelly, M. (2020). Planning classroom instruction. Retrieved from https// www.thoughtco.com/planning-and organizing-instuction-8391

Kennedy, M. F. (1994). Instructional design or personal heuristics in classroom instructional planning. Educational Technology, 34(3), 17-25.

Kezar, A., Chambers, A. C., \& Burkhardt, J. C. (2015). Higher education for the public good: Emerging voices from a national movement. John Wiley \& Sons.

Ko, E. K. (2012). What is your Objective?: Preservice Teachers' Views and Practice of Instructional Planning. International Journal of Learning, 18(7).

Koeller, S., \& Thompson, E. (1980). Another Look at Lesson Planning. Educational Leadership, 37(8), 673-75.

Koh, K., \& Luke, A. (2009). Authentic and conventional assessment in Singapore schools: An empirical study of teacher assignments and student work. Assessment in Education: Principles, Policy \& Practice, 16(3), 291-318.

Kohler, F., Henning, J. E., \& Usma-Wilches, J. (2008). Preparing preservice teachers to make instructional decisions: An examination of data from the teacher work sample. Teaching and Teacher Education, 24(8), 2108-2117.

Lantieri, L. (2001). Why we need schools with heart and soul. Reclaiming children and youth, $10(1), 2$.

Latifa, I. S. (2016). The analysis of teachers' lesson plan through behavioural objectives theory. In Ninth International Conference on Applied Linguistics (CONAPLIN 9). Atlantis Press.

Lee, Y. A., \& Takahashi, A. (2011). Lesson plans and the contingency of classroom interactions. Human Studies, 34(2), 209-227.

Lewis, C. C., \& Tsuchida, I. (1998). A lesson is like a swiftly flowing river: How research lessons improve Japanese education. American Educator, 22(4).

López, Y. A. (1991). Historia documental de la educación en Puerto Rico [History of education in Puerto Rico]. Revised edition. San Juan: Publicaciones Puertorriquenas.

Lorange, P. (2003). Case study: Global responsibility-business education and business schoolsroles in promoting a global perspective. Corporate Governance: The international journal of business in society.

Lucas, C. J. (1994). American higher education: A history. St. Martin's Grif-fin, New York, 126.

Marshall, S. (2012). Improving the quality of e-learning: lessons from the eMM. Journal of Computer Assisted Learning, 28(1), 65-78.

Marzano, R. J. (2011). Classroom management: Whose job is it?.

Marzano, R. J., \& Pickering, D. J. (2001). Special topic: The case for and against homework. Educational leadership, 64(6), 74-79.

Marzano, R. J., Marzano, J. S., \& Pickering, D. (2003). Classroom management that works: Research-based strategies for every teacher. ASCD.

McEwan, E. K. (2002). Seven steps to effective instructional leadership. Corwin Press.

McMunn, N., McColsky, W., \& Butler, S. (2004). Building teacher capacity in classroom assessment to improve student learning. International Journal of Educational Policy Research and Practice, 4, 25-48.

Ministry of Education. (2009), National education policy (2009-2015). Islamabad: Ministry of Education, Government of Pakistan.

Mitchell, T. N. (1999). From Plato to the Internet. Change, 31(2), 17-22

Muijs, D. (2010). Doing quantitative research in education with SPSS. Sage.

Newby, T. J. (1996). Instructional technology for teaching and learning: Designing instruction, integrating computers, and using media. Macmillan College.

Nieves-Falcón, L. (1972). La opinión pública y las aspiraciones de los puertorriqueños. Centro 
de Investigaciones Sociales, Universidad de Puerto Rico.

Ostolaza-Bey, M. (2001). La transformation de la education superior en Puerto Rico. San Juan, PR: Comision de Education, Ciencia y Cultura, Senado de Puerto Rico. http://www.suagm.edu/pdf7Vision_2015_full_version.pdf

Panasuk, R. M., \& Todd, J. (2005). Effectiveness of Lesson Planning: Factor Analysis. Journal of Instructional Psychology, 32(3).

Panasuk, R., Stone, W., \& Todd, J. (2002). LESSON PLANNING STRATEGY FOR EFFECTIVE MATHEMATICS TEACHING. Education, 122(4).

Parr, B., \& Edwards, M. C. (2004). Inquiry-based instruction in secondary agricultural education: Problem-solving-An old friend revisited. Journal of Agricultural Education, 45, 106-117.

Paul, E. L. (2009). Community-based undergraduate research: Collaborative inquiry for the public good. Civic engagement in higher education: Concepts and practices, Jossey Bass, San Francisco, CA.

Pearson, L. C., \& Moomaw, W. (2005). The relationship between teacher autonomy and stress, work satisfaction, empowerment, and professionalism. Educational research quarterly, 29(1), 38-54.

Peterson, P. L., Marx, R. W., \& Clark, C. M. (1978). Teacher planning, teacher behavior, and student achievement. American educational research journal, 15(3), 417-432.

Phelps, P. H. (2006). The three Rs of professionalism. Kappa Delta Pi Record, 42(2), 69-71.

Polk, J. A. (2006). Traits of effective teachers. Arts education policy review, 107(4), 23-29.

Pressley, M., Wharton-McDonald, R., Allington, R., Block, C. C., \& Morrow, L. (1998). The Nature of Effective First-Grade Literacy Instruction.

Print, M. (1993). Curriculum development and design. Malaysia: SRM Production Services Sdn Bhd.

Puerto Rico Planning Board (2007). Statistical appendix of the economic report for the governor and legislative assembly, Table 17, consumer's debt. San Juan, PR: Author.

Quinn, R. E. (2010). Deep change: Discovering the leader within (Vol. 378). John Wiley \& Sons.

Raill, S., \& Hollander, E. (2006). How campuses can create engaged citizens: The student view. Journal of College and Character, 7(1).

Ramaley, J. A. (2000). The perspective of a comprehensive university. Civic responsibility and higher education, 227-248.

Ramaley, J. A. (2005). Scholarship for the public good: Living in Pasteur's quadrant. Higher education for the common good: Emerging voices form a national movement, 166-182.

Reiser, R. A., \& Dick, W. (1996). Instructional planning: A guide for teachers. Allyn and Bacon.

Robinson, B. (1993). Quality, relevance and effectiveness in distance education, Unit 11. Course 2, The Development of Distance Education.

Rusznyak, L., \& Walton, E. (2011). Lesson planning guidelines for student teachers: A scaffold for the development of pedagogical content knowledge. Education as change, 15(2), 271285.

Ryan, K. (2010). Moral education. Retrieved from http://www.education.com/reference/article /moral-education1/

Sachs, J. (2003). Teacher professional standards: controlling or developing teaching?. Teachers and teaching, 9(2), 175-186.

Salman, M. F., Yahaya, L. A., Yusuf, A., Ahmed, M. A., \& Ayinla, J. O. (2012). Effects of Behavioural Objectives-Based Instructional Strategy on Senior School Students' Academic Performance in Mathematics in Omu-Aran, Nigeria. Journal of Education and Learning, 1(2), 121-127.

Santos y Vargas, L. (1992). Crítica filosófica de la educación: escenario puertorriqueño. In Crítica filosófica de la educación: escenario puertorriqueño. (pp. 232-232).

Saptani, D. A. (2016, November). Teachers' Perception towards the Use of Quipper School in Teaching English. In Ninth International Conference on Applied Linguistics 
(CONAPLIN 9) (pp. 233-235). Atlantis Press.

Schneider, C. G. (2005). Liberal education and the civic engagement gap. Higher education for the public good: Emerging voices from a national movement, 127-145.

Schuknecht, H. F., Benitez, J. T., \& Beekhuis, J. (1962). LXXXIII Further Observations on the Pathology of Menière's Disease. Annals of Otology, Rhinology \& Laryngology, 71(4), 1039-1053.

Sesiorina, S. (2014). The Analysis of Teachers' lesson Plan in Implementing Theme-Based Instruction for Teaching English to Young Learners. Journal of English and education, 2(1), 84-95.

Shanker, A. (1985). The making of a profession. The Journal of Negro Education, 55(3), 405421.

Shi, Y., Qin, W., Suo, Y., \& Xiao, X. (2010). Smart classroom: Bringing pervasive computing into distance learning. In Handbook of ambient intelligence and smart environments (pp. 881-910). Springer, Boston, MA.

Shimizu, Y. (2008). Exploring Japanese teachers' conception of mathematics lesson structure: Similarities and differences between pre-service and in-service teachers' lesson plans. ZDM, 40(6), 941-950.

Speck, B. W. (2001). Developing and implementing service-learning programs. Jossey-Bass,.

Spring, K., Grimm Jr, R., \& Dietz, N. (2008). Community Service and Service-Learning in America's Schools. Corporation for National and Community Service.

Šteh, B., \& Požarnik, B. M. (2005). Teachers' perception of their professional autonomy in the environment of systemic change. In Teacher professional development in changing conditions (pp. 349-363). Springer, Dordrecht.

Stephens, J. M., Colby, A., Ehrlich, T., \& Beaumont, E. (2000). Higher Education and the Development of Moral and Civic Responsibility: Vision and Practice in Three Contexts.

Stronge, J. H. (2018). Qualities of effective teachers. ASCD.

Swaner, L. E. (2005). Educating for Personal and Social Responsibility: A Review of the Literature. Liberal Education, 91(3), 14-21.

Técnicos, E. (2007). Informe sobre necesidades sociales en Puerto Rico. San Juan: Publicación de Fondos Unidos de Puerto Rico.

Thomas, N. L. (2000). Community perceptions: What higher education can learn by listening to communities. Development Training Institute \& IORD, Inc., Competency study of leaders who facilitate successful community building initiatives, 26-42.

Tomlinson, C. A., \& McTighe, J. (2006). Integrating differentiated instruction \& understanding by design: Connecting content and kids. ASCD.

Vélez-Cardona, W. (2002). Globalización y educación superior: Del mito "necesario" a un nuevo paradigma. Revista de Educación de Puerto Rico (REduca), (18), 98-114.

Verschoor, C. C. (2003). Is ethics education of future business leaders adequate?. Strategic Finance, 85(2), 20.

Walberg, H. J., \& Paik, S. J. (2000). Effective Educational Practices. Educational Practices Series--3.

Walsh, J. P., Weber, K., \& Margolis, J. D. (2003). Social issues and management: Our lost cause found. Journal of management, 29(6), 859-881.

Warren, K. (1999). A study on behavioral objectives: do they affect learning?.

Webb, M. S., Mayer, K. R., Pioche, V., \& Allen, L. C. (1999). Internationalization of American business education. MIR: Management International Review, 379-397.

Welch, M. (2007). Identifying and Teaching Civic Engagement Skills through Service Leaming. Higher education and civic engagement: International perspectives, 103.

Wellman, J. V. (1999). Contributing to the Civic Good: Assessing and Accounting for the Civic Contributions of Higher Education. The New Millennium Project Working Paper.

Wentzel, K. R. (1998). Social support and adjustment in middle school: The role of parents, teachers, and peers. Journal of Educational Psychology, 90(2), 202-209. 
Werner, W. (2002). Reading visual texts. Theory \& Research in Social Education, 30(3), 401428.

Wharton-McDonald, R., Pressley, M., \& Hampston, J. M. (1998). Literacy instruction in nine first-grade classrooms: Teacher characteristics and student achievement. The elementary school journal, 99(2), 101-128.

Wilen, W., Ishler, M., Hutchison, J., \& Kindsvatter, R. (2000). Dynamics of effective teaching. Addison Wesley Longman, Inc., Allyn \& Bacon, Order Processing Department, PO Box 10695, Des Moines, IA 10695.

Woodward, T. (2001). Designing sequences of work for the language classroom. Penny Ur.(Series Ed.) Planning Lessons and Courses. Cambridge Handbooks for Language Teachers.

Yan Suo (5th July, 2010) Slide share` How to make a lesson plan`. Retrieved from: https://www.slideshare.net/teachersofindia/making-a-lesson-plan

Youniss, J., \& Yates, M. (1997). Community service and social responsibility in youth. University of Chicago Press.

Zahorik, J., Halbach, A., Ehrle, K., \& Molnar, A. (2003). Teaching practices for smaller classes. Educational Leadership, 61(1), 75-77.

Zahorik, J., Halbach, A., Ehrle, K., \& Molnar, A. (2003). Teaching practices for smaller classes. Educational Leadership, 61(1), 75-77.

Zlotkowski, E. (2005). The disciplines and the public good. Higher education for the public good: Emerging voices from a national movement, 146-165.

Zlotkowski, E. (2007). The Case for Service Leaming. Higher education and civic engagement: International perspectives, 37.

Zorić, V. (2016). The Influence of ideas of JF Herbart and the Herbartianism in Slovenia during the Period of the Austro-Hungarian Monarchy. History of Education \& Children's Literature, 11(2). 